\title{
Optimization of fat content to develop goat milk shrikhand
}

\author{
Vivek Sahu ${ }^{1}$, Vikas Pathak ${ }^{2}$, Meena Goswami ${ }^{3}$, Arun Kumar Verma ${ }^{4}$ and Rajkumar V ${ }^{5}$
}

Received: 14 July 2021 / Accepted: 03 October $2021 /$ Published online: 21 December 2021

(C) Indian Dairy Association (India) 2021

\begin{abstract}
The present study was conducted to optimize the fat content of goat milk shrikhand using goat milk with three different fat \% viz. $4.0(\mathrm{~F} 1), 5.0(\mathrm{~F} 2)$ and $6.0(\mathrm{~F} 3) \%$. The $\mathrm{pH}$ values decreased while titratable acidity increased significantly $(\mathrm{P}<0.05)$ with increased fat content. Fat content and brix values increased significantly $(\mathrm{P}<0.05)$ with increased fat content in goat milk. All textural parameters i.e. firmness, consistency, cohesiveness and work of cohesiveness increased significantly $(\mathrm{P}<0.05)$ with increased fat content. Among the sensory attributes, there was no significant difference in color and appearance, texture and mouth coating scores among the treatments; however flavor, sweetness and overall acceptability scores increased significantly $(\mathrm{P}<0.05)$ with increased fat content. There was no significant difference between F2 and F3 for any sensory attribute including overall acceptability. Present day health conscious consumer demand product with lower fat content without compromising with taste and flavour. Therefore, F2- goat milk shrikhand prepared with $5.0 \%$ fat was found optimum and selected as the best treatment.
\end{abstract}

Keywords: Goat milk shrikhand, Fat content, Optimization, Textural and colour parameter, Sensory evaluation.

\footnotetext{
1,2,3,4 Department of Livestock Products Technology, College of Veterinary Sciences and Animal Husbandry, DUVASU, Mathura-281 001

${ }^{5}$ Division of Goat Products Technology Laboratory, Central Institute for Research on Goats, Makhdoom, Farah-281122, Mathura, UP, India

Meena Goswami $(\square)$

Department of Livestock Products Technology, College of Veterinary Sciences and $\mathrm{AH}$

DUVASU, Mathura, (U.P.), India. Pin-281001

e-mail Id: dr.goswami2008@yahoo.co.in

Mob: +919997323852
}

\section{Introduction}

India is leading milk producer in the world with 187.7 million tonnes of milk (NDDB, 2019) due to advancement of technology, proper nutrition and appropriate managemental practices. Livestock contributes about $9.2 \%$ in gross value added (GVA) and $26.2 \%$ in agriculture sector in India. The livestock population in India includes 302.3 million bovines, 74.3 million sheep, 148.9 million goats, about 9.1 million pigs and 851.8 million poultry. The rural and urban population of goat is 129.081 million and 6.092 million respectively in India. Total goat milk production in India is 6.09 million tones, out of which Rajasthan and Uttar Pradesh produce 2.31 million tonnes and 1.34 million tonnes respectively (DAHD, 2019). Goat milk production is a dynamic and growing industry that is fundamental to the wellbeing of millions people worldwide and is an important part of the economy in India. Goat milk is having better digestibility, alkalinity, buffering capacity and certain therapeautic values in medicine and human nutrition (Park and Chukwu, 1989; Park, 1994) in comparison to cow's or human milk. The goat milk microbiota is also considered a good source of novel bacteriogenic Lactic acid bacteria (LAB) strains that can be exploited as an alternative for use as bio preservative in food (Perin and Nero, 2014). It is also rich source of amino acid, being 20-40 folds higher than cow milk (Mehaia and Al-Kanhal, 1992) which is involved in bile salt formation, osmoregulation, antioxidation, calcium transport and in the central nervous system (Redmond et al. 1998). Minerals content such as calcium, potassium, magnesium and chloride as well as vitamin A, B, C, D, thiamin and niacin content of goat milk is higher than that of cow milk (Chandan et al. 1992). Goat milk also contains higher content of three characteristics fatty acids i.e. caproic acid, caprylic and capric acid which are having medicinal values for patients suffering from malabsorption, childhood epilepsy, cystic fibrosis and gallstones (Haenlin, 1992); however these are responsible for intense "goaty flavour" which limits the acceptability of goat milk products among the consumers (Ozer et al. 2017).

Traditional dairy foods have always played a pivotal role in preservation of precious milk nutrients and promotion of its consumption among masses. Shrikhand is one of the widely 
relished indigenous milk product prepared by the fermentation of milk by using known strain of lactic acid bacteria. It is very much popular in western part of India due to its high nutritive, characteristics flavour, taste, palatable nature and possible therapeutic value. Shrikhand contains appreciable amount of milk protein and phospholipids and is obtained by lactic acid fermentation through the action of starter culture consisting Lactobacillus bulgaricus, Streptococcus lactis, Streptococcus diacetylactis, Lactobacillus citrovoroum and Streptococcus thermophilus. It is produced from chakka which in turn is obtained from dahi (curd) after draining off the whey. The basic ingredients sugar, colour and flavour are thoroughly mixed into chakka and to form a sort homogenous mass called Shrikhand (Desai and Gupta, 1986). The popularity of fermented dairy products from goats' milk has shown a gradual increase all over the world due to its better functional properties and health benefits. As per FSSAI (2016), shrikhand should contain 58\% total solids (min.), $8.5 \%$ fat (min.) $9.0 \%$ protein (min.), $1.4 \%$ titratable acidity (max.) and $0.9 \%$ ash (maximum). Fat is a very important ingredient contributing to the texture, flavor and overall perception of dairy products. Milk fat has a complex and rich chemical composition and provides unique sensorial properties (flavor and mouthfeel) to milk and milk products.

Consumers are becoming increasingly conscious nowadays about their nutrition, hygiene and wellbeing. Consumption of more fat and calories has been related to the coronary hear diseases, and obesity (Law et al. 1991). There is evidence tha high fat intake is associated with increased risk of obesity, cance1 high blood cholesterol and coronary heart diseases (Garcia et a] 2002). The number of patients with cardiovascular diseases $i$ growing rapidly in India, so there is a dire need to develo functional products with low fat content (Anand et al. 2015) Present day health conscious consumer demand a healthy produc with less fat content, again dairy products from goat milk ha less acceptability in terms of flavour and aroma due to presenc of medium chain fatty acids. Therefore, development of shrikhan with low fat goat milk may be a technological challenge wit higher organoleptic and nutritional quality. Keeping these view in mind, present study was carried out to optimize the fat conten of goat milk shrikhand with well acceptability in terms of nutrien content and sensory evaluation.

\section{Materials and Methods}

The experiments were carried out in the Department of Livestoc Products Technology, College of Veterinary Sciences and Anima Husbandry, U.P. Pt. Deen Dayal Upadhyaya Pashu Chikitsa Vigya Vishwavidyalaya Evam Go-Anusandhan Sansthan, Mathura 281001 (UP), India. Fresh clean wholesome milk of goat wa procured from Department of Veterinary Physiology, DUVASU Mathura. Starter culture (NCDC-159) was procured from NDR] Karnal which contained mixed culture of Lactococcus lactis Lactococccus diacetylactis and Lactococcus cremoris. Th culture was activated to as per the standard method and the activated parent culture was maintained by sub culturing and stored under refrigeration. Clean crystalline sugar was procured from local market of Mathura. All the chemicals used in the study were of analytical grade and procured from Hi Media laboratories (P) Ltd, Mumbai.

\section{Preparation of Shrikhand}

The shrikhand was prepared as per method described by Gupta et al. (2018) with slight modifications. Fresh goat milk was filtered through muslin cloth and then fat content was standardized using Pearson square method, where skimmed milk powder or cream was added to adjust fat content in milk. Then milk was subjected to heat treatment at $85^{\circ} \mathrm{C}$ for 30 minutes followed by cooling at $37 \pm 2^{\circ} \mathrm{C}$. Milk was inoculated with NCDC- $159 @ 2.5 \%$ by v/v of milk and incubated at $35-37^{\circ} \mathrm{C}$ for $12-15$ hours for proper curd setting. The curd thus obtained was transferred to clean muslin cloth and hanged for 16-18 hours in order to drain the whey to obtain chakka. The chakka was kneaded to have uniform consistency and then mixed with $30 \%$ ground sugar. Finally shrikhand was filled in pre sterilized thermorigid polypropylene cups and stored at under refrigeration at $4 \pm 2^{\circ} \mathrm{C}$. In present study, following abbreviations were used for present experiment: F1goat milk shrikhand prepared with $4.0 \%$ fat, F2- goat milk

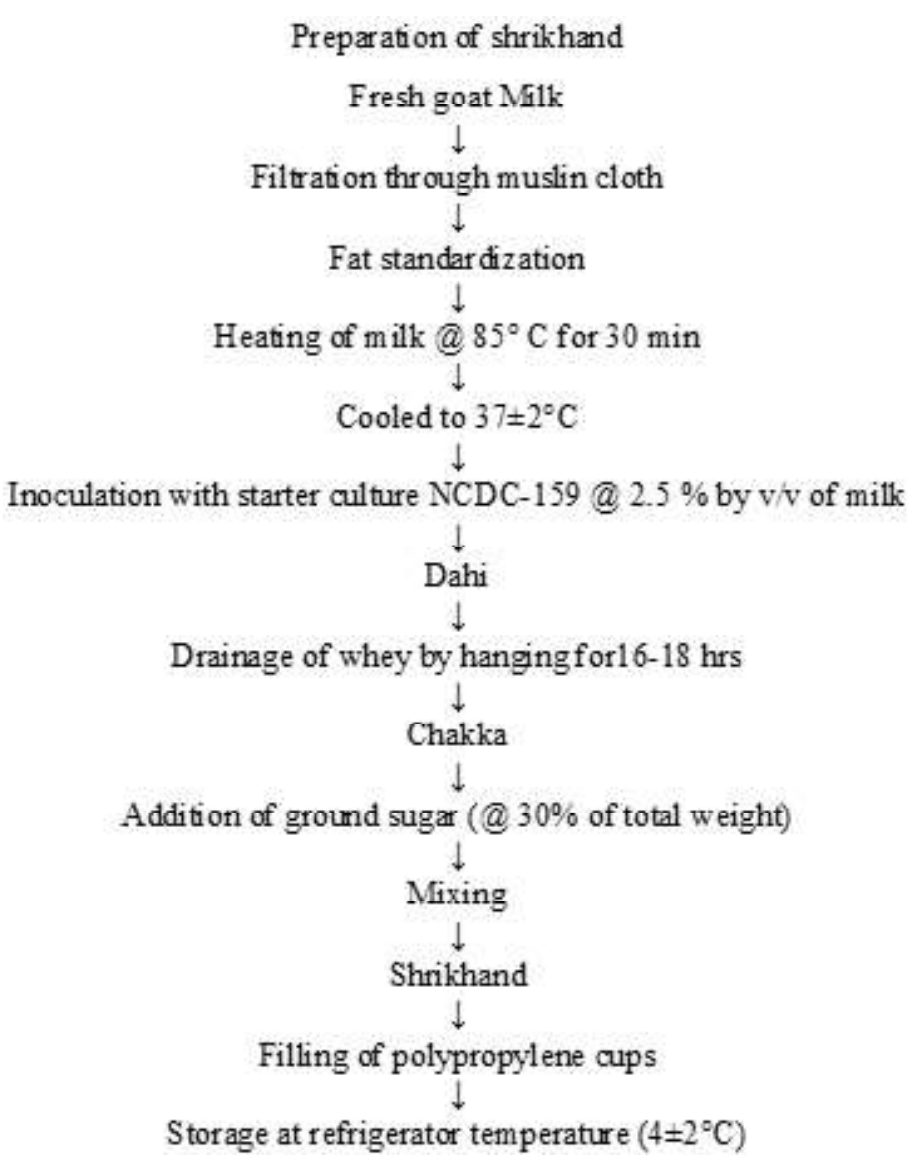


shrikhand prepared with $5.0 \%$ fat and F3- goat milk shrikhand prepared with $6.0 \%$ fat.

\section{Analytical methods}

\section{Physic-chemical properties}

The $\mathrm{pH}$ of shrikhand was determined by using digital $\mathrm{pH}$ meter (WTW, Germany, model pH 330i) as per method given by Trout et al. (1992). Water activity of each sample was measured three times in duplicate using a water activity meter (AquaLab $3 \mathrm{TE}$, Inc. Pullman, WA) at Department of Goat Products Technology, CIRG, Makdhoom. Proximate parameters viz. moisture, protein, fat and ash content were estimated as per AOAC (1995).

\section{Textural and colour parameters}

The texture profile analysis of shrikhand was done with the help of instrumental texture profile analyser (TA HD Plus Texture analyser) for firmness, consistency, cohesiveness and work of cohesiveness (Bourne, 1978). Texture analyzer equipped with 5 $\mathrm{kg}$ load cell and back extrusion test using $35 \mathrm{~mm}$ cylinder probe was used for texture profile analysis of the samples. Other conditions (test descriptions) set for analyses were as follows:

Mode:

option:

Pre-test speed:

Measure force in compression

Test speed :

Return to start

Post-test speed :

$1 \mathrm{~mm} / \mathrm{sec}$

$1 \mathrm{~mm} / \mathrm{sec}$

Distance :

$10 \mathrm{~mm} / \mathrm{sec}$

Trigger type:

$30 \mathrm{~mm}$

Trigger force:

Auto (F) $-10 \mathrm{~g}$

$0.04903 \mathrm{~N}$

Auto

400pps

Data acquisition rate :

Back extrusion cell (A/BE)

The colour parameters i.e. lightness $\left(L^{*}\right)$, redness $\left(a^{*}\right)$ and yellowness $\left(b^{*}\right)$ of the shrikhand were measured using Hunter colourimeter of ColourTech PCM+ (Colour Tec Associates Inc. Clinton NJ, USA) at Department of Goat Products Technology, CIRG, Makdhoom.

\section{Sensory evaluation}

Sensory evaluation was conducted by experienced semi trained panellists using 8-point descriptive scale (where $1=$ extremely disliked and $8=$ extremely liked) (Keeton, 1983) for colour and appearance, flavour, texture, sweetness, mouth coating and overall acceptability.

\section{Statistical analysis}

The data obtained in the study on various parameters were statistically analyzed on 'SPSS-16.0' software package as per standard methods of Snedecor and Cochran (1995). Duplicate samples were drawn for each parameter and the experiment was replicated thrice $(n=6)$. Sensory evaluation was performed by a panel of seven member judges three times, so total observations being $21(n=21)$ Data were subjected to one way analysis of variance, homogeneity test and Duncan's Multiple Range Test (DMRT) for comparing the means to find the effects between samples.

\section{Results and Discussion}

\section{Composition of goat milk}

Total 30 goat milk samples were evaluated for proximate composition and reported to have following composition on an average as per table 1 .

Ibrahim et al. (2020) also reported the average composition of fresh goat milk as $3.54 \%$ protein, $3.25 \%$ lactose, $6.68 \%$ fat and $6.82 \%$ SNF respectively. These differences in fat content might be due to animal type, oldness, competition, season, location, and feedstuffs (Contreras et al. 2015). Santis et al. (2019) developed goat milk yogurt with probiotic culture containing Streptococcus thermophilus, Lactobacillus delbrueckii spp. bulgaricus, with cultures of Leuconostoc lactis and fresh raw milk was standardized at $3.74 \%$ fat, p3.47\% rotein, 3.92\%lactose and $\mathrm{pH}$ 6.91. Based on available literature, several preliminary trials were conducted to standardize the processing technology of goat milk shrikhand. The final formulation of goat milk shrikhand was optimized following the method prescribed by Gupta et al. (2018) with slight modifications as milk was standardized at lower fat content, again due to poor rheological properties and soft curd formation from goat milk, temperature time combination was changed as per the standard method. The curd was also hanged up for comparatively more time (16-18 hours) as compared to standard method.

\section{Physico-chemical properties}

The physico-chemical properties of goat milk shrikhand prepared with different fat content are presented in table 2 . The $\mathrm{pH}$ values decreased while titratable acidity increased significantly $(\mathrm{P}<0.05)$ with increased fat content, however there was no significant difference in titratable acidity of F1 and F2. The $\mathrm{pH}$ of product in present study (4.24 to 4.57) is in agreement with the range of 4.15 to 4.50 given in the literature (Kavas et al. 2003; Matos et al. 2013). There was no significant difference in proximate parameters i.e. moisture, protein and ash content except fat content which

Table 1 Proximate composition of goat milk $(\mathrm{n}=30)$

\begin{tabular}{llc}
\hline S. No. & Component & $\%$ \\
\hline 1 & Fat & 5.32 \\
2 & SNF & 7.79 \\
3 & Lactose & $4.3 \%$ \\
4 & Protein & 2.84 \\
\hline
\end{tabular}


increased significantly $(\mathrm{P}<0.05)$ with increased fat content in goat milk. There was no significant difference in water activity among the treatments; however brix value increased significantly $(\mathrm{P}<0.05)$ with increased fat content. Higher brix values with increased fat content in shrikhand might be due to higher viscosity and compactness of product with increased fat content. Falke (2015) also observed significant $(\mathrm{P}<0.05)$ increase in brix values of yogurt with increased fat content and addition of inulin due to higher solid content.

\section{Textural and colour parameters}

The values of textural and colour parameters of goat milk shrikhand prepared with different fat content are presented in table 3 . All textural parameters i.e. firmness, consistency, cohesiveness and work of cohesiveness increased significantly $(\mathrm{P}<0.05)$ with increased fat content; where no significant difference was observed between F2 and F3 in cohesiveness values. Higher textural parameters values with increased fat content might be due to more firm and smooth curd/chakka produced by milk containing higher fat percentage. Somayeh et al. (2017) also reported higher hardness and consistency values of yogurt with increased fat content. Amatayakul et al. (2006) and Soukoulis et al. (2007) also reported that the change in fat content of milk might significantly $(\mathrm{P}<0.05)$ effect the firmness and other textural parameters of fermented milk products. There was no significant difference in lightness, redness and yellowness values among the treatments due to no effect of fat content variation in colour of milk and milk products. Chudy et al. (2020) reported that natural colour of milk is due to the reflection of light by dispersed fat globules, calcium caseinate and calcium phosphate.

\section{Sensory evaluation}

The sensory scores of goat milk shrikhand prepared with different fat content are presented in table 4. Fat has an important role in the development of flavor, texture and appearance of milk products (Sipahioglu et al. 1999). There was no significant difference in color and appearance, texture and mouth coating scores among the treatments; however flavor, sweetness and overall acceptability scores increased significantly $(\mathrm{P}<0.05)$ with increased fat content. $\mathrm{F} 2$ had significantly $(\mathrm{P}<0.05)$ higher flavor scores than $\mathrm{F} 1$; however scores of $\mathrm{F} 3$ were comparable to $\mathrm{F} 1$ and F2. F3 had slightly lower flavour scores than F2 inspite of higher fat content due to pronounced goaty flavour at higher fat content in milk. As per Park et al. (2007), caprylic, capric, and caproic acid present in goat milk might lower the acceptability of goat milk products due to goaty aroma and flavour. Singh et al. (2015)

Table 2 Physio-chemical properties (Mean \pm SE) of goat milk shrikhand prepared with different fat content

\begin{tabular}{lllll}
\hline Parameters & F1 & F2 & F3 & Treatment Mean \\
\hline pH & $4.57^{\mathrm{a}} \pm 0.03$ & $4.40^{\mathrm{b}} \pm 0.01$ & $4.24^{\mathrm{c}} \pm 0.02$ & $4.40 \pm 0.03$ \\
Titratable acidity & $0.41^{\mathrm{b}} \pm 0.05$ & $0.42^{\mathrm{b}} \pm 0.01$ & $0.46^{\mathrm{a}} \pm 0.01$ & $0.43 \pm 0.01$ \\
Moisture (\%) & $47.43 \pm 0.51$ & $47.18 \pm 0.39$ & $46.96 \pm 0.39$ & $47.19 \pm 0.24$ \\
Protein (\%) & $6.55 \pm 0.06$ & $6.52 \pm 0.05$ & $6.51 \pm 0.09$ & $6.52 \pm 0.03$ \\
Fat (\%) & $10.25^{\mathrm{c}} \pm 0.11$ & $13.96^{\mathrm{b}} \pm 0.20$ & $15.43^{\mathrm{a}} \pm 0.26$ & $13.21 \pm 0.54$ \\
Ash (\%) & $0.64 \pm 0.02$ & $0.65 \pm 0.01$ & $0.66 \pm 0.01$ & $0.65 \pm 0.01$ \\
Water activity & $0.948 \pm 0.07$ & $0.941 \pm 0.26$ & $0.938 \pm 0.13$ & $0.942 \pm 0.10$ \\
Brix value & $27.82^{\mathrm{c}} \pm 0.02$ & $31.29^{\mathrm{b}} \pm 0.02$ & $33.46^{\mathrm{a}} \pm 0.04$ & $30.85 \pm 0.02$ \\
\hline
\end{tabular}

F1- goat milk shrikhand prepared with $4.0 \%$ fat

F2- goat milk shrikhand prepared with $5.0 \%$ fat

F3- goat milk shrikhand prepared with $6.0 \%$ fat

$\mathrm{n}=6$

Table 3 Textural and colour parameters (Mean \pm SE) of goat milk shrikhand prepared with different fat content

\begin{tabular}{lllll}
\hline Parameters & F1 & F2 & F3 & Treatment Mean \\
\hline Firmness & $66.74^{\mathrm{c}} \pm 0.32$ & $67.91^{\mathrm{b}} \pm 0.16$ & $69.00^{\mathrm{a}} \pm 0.19$ & $67.55 \pm 0.35$ \\
Consistency & $43.36^{\mathrm{c}} \pm 0.13$ & $44.30^{\mathrm{b}} \pm 0.11$ & $45.97^{\mathrm{a}} \pm 0.17$ & $44.54 \pm 0.27$ \\
Cohesiveness & $32.24^{\mathrm{b}} \pm 0.31$ & $33.70^{\mathrm{a}} \pm 0.12$ & $33.98^{\mathrm{a}} \pm 0.12$ & $33.31 \pm 0.19$ \\
Work of cohesiveness & $25.37^{\mathrm{c}} \pm 0.18$ & $26.54^{\mathrm{b}} \pm 0.14$ & $27.36^{\mathrm{a}} \pm 0.11$ & $26.42 \pm 0.21$ \\
Lightness $\left(L^{*}\right)$ & $76.23 \pm 0.02$ & $77.92 \pm 0.01$ & $77.89 \pm 0.02$ & $77.34 \pm 0.01$ \\
Redness $\left(a^{*}\right)$ & $4.42 \pm 0.11$ & $4.52 \pm 0.08$ & $4.48 \pm 0.09$ & $4.47 \pm 0.05$ \\
Yellowness $\left(b^{*}\right)$ & $7.25 \pm 0.10$ & $7.21 \pm 0.09$ & $7.11 \pm 0.11$ & $7.19 \pm 0.05$ \\
\hline
\end{tabular}

F1- goat milk shrikhand prepared with $4.0 \%$ fat

F2- goat milk shrikhand prepared with $5.0 \%$ fat

F3- goat milk shrikhand prepared with $6.0 \%$ fat

$\mathrm{n}=6$ 
Table 4 Sensory evaluation (Mean \pm SE) of goat milk shrikhand prepared with different fat content

\begin{tabular}{lllll}
\hline Attributes & F1 & F2 & F3 & Treatment Mean \\
\hline Colour and appearance & $6.81 \pm 0.04$ & $6.90 \pm 0.14$ & $6.92 \pm 0.04$ & $6.88 \pm 0.05$ \\
Flavour & $6.55^{\mathrm{b}} \pm 0.09$ & $6.87^{\mathrm{a}} \pm 0.07$ & $6.75^{\mathrm{ab}} \pm 0.08$ & $6.72 \pm 0.04$ \\
Texture & $6.69 \pm 0.13$ & $6.77 \pm 0.08$ & $6.68 \pm 0.08$ & $6.71 \pm 0.05$ \\
Sweetness & $6.67^{\mathrm{b}} \pm 0.09$ & $6.98^{\mathrm{a}} \pm 0.07$ & $7.01^{\mathrm{a}} \pm 0.09$ & $6.88 \pm 0.05$ \\
Mouth coating & $6.53 \pm 0.07$ & $6.87 \pm 0.07$ & $6.89 \pm 0.08$ & $6.76 \pm 0.04$ \\
Overall acceptability & $6.79^{\mathrm{b} \pm 0.07}$ & $6.99^{\mathrm{a}} \pm 0.05$ & $7.01^{\mathrm{a}} \pm 0.04$ & $6.93 \pm 0.03$ \\
\hline
\end{tabular}

F1- goat milk shrikhand prepared with $4.0 \%$ fat

F2- goat milk shrikhand prepared with $5.0 \%$ fat

F3- goat milk shrikhand prepared with $6.0 \%$ fat

$\mathrm{n}=21$

developed shrikhand with different levels of fat and sugar and observed that shrikhand prepared with $6 \%$ fat and $40 \%$ sugar had highest overall acceptability among the treatments. Shelke et al. (2014) also reported that well acceptable low fat low sugar mango flavoured shrikhand was prepared with $70 \%$ skimmed milk based chakka and $40 \%$ sugar. Sweetness and overall acceptability scores of $\mathrm{F} 2$ and $\mathrm{F} 3$ were significantly $(\mathrm{P}<0.05)$ higher than $\mathrm{F} 1$ in present study; however there was no significant difference between F2 and F3.Present day health conscious consumer demands for low fat products without compromising the organoleptic qualities. Therefore, keeping the view of health concern, F2- goat milk shrikhand prepared with $5.0 \%$ fat was found optimum in terms of nutrient content and sensory properties.

\section{Conclusions}

People all over the world are more heath conscious and choosing healthy diet options to maintain a healthy lifestyle. Increasing awareness about health benefits related to low-fat dairy products among the global population is expected to propel its demand across the globe. The present study was conducted to optimize the fat content of goat milk shrikhand which was a challenge due to lower fat content and total solid content in goat milk alongwith poor textural properties and soft curd formation. However, increasing fat content in goat milk had significant effect on textural and colour parameters. Fat content also improved sensory qualities of product in terms of flavour, sweetness and overall acceptability scores. Goat milk shrikhand prepared with $5.0 \%$ fat was selected as the best treatment. Goat milk products have lower acceptability among people inspite of their medicinal properties and easy digestibility due to presence of medium chain fatty acids like capric, caprylic acids, therefore further research may be recommended for incorporation of fruit pulp and other natural flavoruing compounds in goat milk shrikhand to improve it's acceptability.

\section{References}

Amatayakul T, Halmos AL, Sherkat F, Shah NP (2006) Physical characteristics of yoghurts made using exopolysaccharide-producing

starter cultures and varying casein to whey protein ratios. Int Dairy J 16: 40-51

Anand SS, Hawkes C, de Souza RJ, Mente A, Dehghan M, Nugent R, Zulyniak MA, Weis T, Bernstein AM, Krauss RM, Kromhout D, Jenkins D, Malik V, Martinez-Gonzalez MA, Mozaffarian D, Yusuf S, Willett WC, and Popkin BM (2015) Food Consumption and its Impact on Cardiovascular Disease: Importance of Solutions Focused on the Globalized Food System: A Report From the Workshop Convened by the World Heart Federation. J Am Coll Cardiology 66: 1590-1614. https://doi.org/10.1016/j.jacc.2015.07.050

AOAC (1995) Official Methods of Analysis. 17 $7^{\text {th }}$ edition Association of Official Analytical Chemists, Washington, DC

Bourne MC (1978) Texture Profile Analysis. Food Technol 32: 62-66

Chandan RC, Attaie R, Shahani KM (1992) March. Nutritional aspects of goat milk and its products. In Proc V Int Conf Goats pp. 399

Chudy S, Bilska A, Kowalski R, Teichert J (2020) Colour of milk and milk products in CIE L* a* b* space. Medycyna Weterynaryjna 76: 77 81

Contreras VIP, Gaspar MPB, Luis ALB, Víctor RMM and Ana MSR (2015) Milk Composition and Its Relationship with Weaning Weight in Charolais Cattle. Revista Brasileira de Zootecnia 44: 207-212

DAHD (2019) Basic animal husbandry \& fisheries statistics (http:// dahd.nic.in/Division/statistics/animal-husbandry-statistics-division)

Desai HK, Gupta SK (1986) Sensory evaluation of Shrikhand. Dairy Guide 8: 33

Falke S (2015) Development of a synbiotic drinkable yogurt for schoolaged children (Doctoral dissertation, Kansas State University). FSSAI

Compendium_Food_Additives_Regulations_29_03_2019\%20(2).pdf

Garcia M.L, Dominguez R, Galvez (2002) Utilization of cereal and fruit fibers in low fat fermented sausages. J Meat Sci 60: 227-236.

Gupta G, David J, Shukla G, Dubey S, Shukla, A (2018) Studies on quality of Shrikhand by blending papaya and banana pulp. The Pharma Inno J 7: 415-417.

Haenlein GFW (1992) March. Role of goat meat and milk in human nutrition. In Proceedings of the Fifth International Conference on Goats (Vol. 2, No. part II, pp. 575-580).Indian Council of Agricultural Research Publishers.

Ibrahim A, Naufalin R, Muryatmo E and Dwiyanti H (2021) Comparative study between cow and goat milk yogurt based on composition and sensory evaluation. IOP Conf. Series: Earth and Environl Sci 746.doi:10.1088/1755-1315/746/1/012001

Kavas G, Uysal H, Kilic S, Akbulut N, Kesenkas H (20030 Some properties of yogurt produced from goat milk and cow-goat milk mixtures by different fortification methods. Pakistan J Biol Sci 69: 1936-1939.

Keeton JT (1983) Effect of fat and sodium chloride / phosphate levels on the chemical and sensory properties of pork patties. J Food Sci 48: 878-81. 
Law N, Frost C, Wald N (1991) By how much dietary salt reduction lower blood pressure, analysis of observational data among population. Brit Med J 301: 811-815.

Matos S, Pinto A, Castilho C, Correia PR, Monteiro AC (2013) Mix goat and sheep yogurt: development and product characterization. In Proceedings of World Academy of Science, Engineering and Technology (No. 79, p. 524).World Academy of Science, Engineering and Technology (WASET).

Mehaia MA, Al-Kanhal MA (1992) Taurine and other free amino-acids in milk of camel, goat, cow and man. Milchwissenschaft 47: 351-353.

NDDB (2019) https://www.nddb.coop/information/stats/milkprodindia

Kesenkas H, Karagozl U, Yerlikaya O, Ozer, E, Akpinar A and Akbulut N (2017) Physico- chemical and sensory characteristics of winter yogurt produced from mixtures of cow's and goat's milk. J Agric Sci 23: 53-62.

Park YW, Chukwu HI (1989) Macro-mineral concentrations in milk of two goat breeds at different stages of lactation. Small Ruminant Res 1:157-166.

Park YW, Juárez M, Ramos M and Haenlein GFW (2007) Physico-chemical characteristics of goat and sheep milk. Small Ruminant Res 68: 88113.

Park YW (1994) Hypo-allergenic and therapeutic significance of goat milk. Small Ruminant Res 14:151-159.

Perin LM, Nero LA (2014) Antagonistic lactic acid bacteria isolated from goat milk and identification of a novel nisin variant lactococcuslactis. BMC Microbiol 12:14-36.

Redmond HP, Stapelton PP, Neary P, Bouchier-Hayes D (1998) Immunonutrition: the role of taurine. Nutri 14: 599-604.

Santis DD, Giuseppina G, Giulia C and Maria TF (2019) Improvement of the Sensory Characteristics of Goat Milk Yogurt. J Food Sci. doi: 10.1111/1750-3841.14692

Shelke, PA, Shegokar SR, Shelke RR, Kahaate PA and Chavan SD (2014) Studies on prepration of low fat, sugar free mango shrikhand. Res J Anim Husbandry Dairy Sci 5(2): 122-125.
Singh M, Gupta R, Andhare BC, Singh S (2015) Effect of fat and sugar on sensory quality of shrikhand. Res J Anim Husb Dairy Sci 6: 52-56.

Sipahioglu O, Alvarez VB, Solano-Lopez C (1999) Structure, physicochemical and sensory properties of Feta cheese made with tapioca starch and lecithin as fat mimetics. Int Dairy J 9: 783-789.

Snedecor GW, Cochran WG (1995) Statistical Methods, 8th edition Pp.72148. New Delhi: oxford and IBH Publishing Company.

Somayeh P, Tehrani MM, Razavi SMA (2017) Optimization of low-fat set-type yoghurt: effect of altered whey protein to casein ratio, fat content and microbial transglutaminase on rheological and sensorial properties. J Food Sci Technol 54: 2351-2360.

Soukoulis C, Panagiotidis P, Koureli R, Tzia C (2007) Industrial yogurt manufacture: monitoring of fermentation process and improvement of final product quality. J Dairy Sci 90: 2641-2654.

Trout ES, Hunt NC, Johnson DE, Claus JR, Kastner CL, Kropf DH, Stroda $\mathrm{S}$ (1992) Chemical, physical, and sensory characterization of ground beef containing 5 to 30 percent fat. J Food Sci 57:25-29 